\title{
A Multiplex PCR Assay for the Detection of Food-borne Pathogens in Meat Products
}

\author{
Hyoun Wook Kim, Ji-Hyun Kim, Seong-Ryul Rhim¹, Kyung-A Lee ${ }^{2}$, Cheon-Jei Kim, and Hyun-Dong Paik* \\ Division of Animal Life Science and Bio/Molecular Informatics Center, Konkuk University, Seoul 143-701, Korea \\ ${ }^{1}$ Department of Biomedical Science, Hallym University, Chuncheon 200-702, Korea \\ ${ }^{2}$ Department of Food and Nutrition, Donga University, Busan 604-714, Korea
}

\begin{abstract}
Meat and meat products are a potential source of food-borne pathogens, including Staphylococcus aureus, Salmonella spp., Escherichia coli O157:H7, and Bacillus cereus. A sensitive and specific PCR assay for the detection of these pathogens in meat and meat products was developed in this study, as part of a broader effort to reduce the potential health hazards posed by these pathogens. Initially, PCR conditions were standardized with purified DNA. Under standard conditions, the detection level for PCR was as low as $10 \mathrm{pg}$ of purified bacterial DNA. After overnight growth of bacteria in a broth medium, as few as $10^{2} \mathrm{CFU}$ of bacteria were detected by PCR assay. The primers employed in the PCR assay were found to be highly specific for individual organisms, and evidenced no cross-reactivity with heterologous organisms. Additionally, the multiplex PCR assays also amplified some target genes from the four pathogens, and multiplex amplification was obtained from as little as 10 pg of DNA, thus illustrating the excellent specificity and high sensitivity of the assay. In conclusion, this PCR-based technique provides a sensitive and specific method for the detection of S. aureus, Salmonella spp., E. coli $\mathrm{O} 157: \mathrm{H} 7$, and $B$. cereus in meat and meat products.
\end{abstract}

Key words: meat product, food safety, food-borne pathogen, multiplex PCR assay

\section{Introduction}

The microbiological safety of food constitutes a significant concern for both consumers and industries today. The rapid and accurate identification of bacterial pathogens in foods is important with regard to both quality assurance and the tracing of bacterial pathogens within the food supply (Bhagwat, 2003). In 2000, 49\% of patients visiting hospitals for the treatment of food-borne diseases had consumed contaminated meat or meat products, and the incidence of food-borne diseases caused by pathogenic bacteria is increasing annually in Korea (Kim et al., 2008)

Escherichia coli $\mathrm{O} 157: \mathrm{H} 7$ is an important verotoxinproducing strain of E. coli (VTEC) that is generally associated with food-borne and water-borne infections (Sarimehmetoglu et al., 2009). The pathogen has been implicated in large food-borne outbreaks all over the

\footnotetext{
*Corresponding author: Hyun-Dong Paik, Division of Animal Life Science and Bio/Molecular Informatics Center, Konkuk University, Seoul 143-701, Korea. Tel: 82-2-2049-6011, Fax: 82-2-455-1044, E-mail: hdpaik@konkuk.ac.kr
}

world, including in Canada, UK, Scotland, and Japan. Escherichia coli $\mathrm{O} 157: \mathrm{H} 7$ has been shown to cause several disease syndromes, including diarrhea, hemorrhagic colitis, hemolytic uremic syndrome, and thrombotic thrombocytopenic purpura in humans (Choi et al., 2010; Gooding and Choudary, 1997). Additionally, enterotoxigenic Staphylococcus aureus is one of the major pathogens responsible for cases of food poisoning all over the world (Dinges et al., 2000). The emetic staphylococcal enterotoxins (SE) are classified as members of the pyrogenic toxin superantigen family, owing to their biological activities and structural relatedness (Balaban and Rasooly, 2000; Dinges et al., 2000). Eleven major antigenic types of SEs have been recognized thus far (SEA to SEJ) (Jarraud et al., 1999; Monday and Bohach, 1999; Tamarapu et al., 2001), and their corresponding genes have been reported in previous studies (Munson et al., 1998). Strains of Salmonella can cause general infection, food poisoning, and salmonellosis, a zoonotic disease of significant importance (Davies and Hinton, 2000). Salmonellosis and listeriosis are two of the most common foodborne diseases (Anonymous, 2001; Mead et al., 1999), and early and sensitive detection is a critical issue in pub- 
lic health policy (Rijpens and Herman, 2002). Bacillus cereus is a Gram-positive, spore-forming, facultative-aerobic bacteria. $B$. cereus is the dominant aerobic bacterium in cooked, pasteurized, and chilled products, owing to the ability of spores to survive during the pasteurization process. Bacillus spp. have also been detected in other cooked and chilled foods (Choma et al., 2000; Simpson et al., 1994).

The development of rapid, sensitive, and infallible methods for the detection of food-borne pathogens has received a great deal of attention in recent years, owing to an increased public awareness regarding the health hazards associated with microbial contamination of food. Current methods for the detection of food-borne pathogens generally involve the following: (a) colony isolation on selective media, (b) the use of biochemical tests, and (c) serotyping using antibodies against specific bacterial antigens. These procedures are both cumbersome and timeconsuming. In certain cases, it can take several days to establish the identity of particular bacteria. Therefore, new approaches to milk safety are necessary for the rapid and efficient detection of the low numbers of bacteria likely to be present in milk. In recent years, several methods have been tested to facilitate the identification of bacteria in foods. Molecular techniques such as PCR have been extensively employed for several years for the identification and characterization of bacteria in food samples, including meat and dairy products (Hill, 1996; Wang et al., 1997). However, these assays involved the use of selective enrichment techniques to recover bacteria in food samples, and 48-72 $\mathrm{h}$ were required for confident identification of the bacteria. Conventional methods of bacteria detection in food involve propagation in selective enrichment media, followed by microbiological and biochemical tests, which are both cumbersome and timeintensive. The advent of nucleic-acid based assay systems such as the polymerase chain reaction (PCR) has resulted in the emergence of improved, expedient, and reliable microbial identification and surveillance techniques, which are capable of detecting even nonviable cells (Josephson et al., 1993; Scheu et al., 1998). The direct detection of pathogenic bacteria in food samples constitutes a challenging task, hampered by the presence of PCR-inhibitory substances frequently associated with enrichment media, DNA isolation reagents and the food matrix itself, and further compounded by the presence of large numbers of indigenous microflora (Rossen et al., 1992; Wilson, 1997). Consequently, a clear need exists for the development of a sample preparation strategy that can effec- tively sequester the pathogenic bacteria or the target DNA from the food sample. In order to achieve this improved sample preparation, methods have been designed on the basis of enzymatic treatment, buoyant density centrifugation, DNA affinity purification columns, and magnetic beads coated with specific antibodies or lectins (Lindqvist et al., 1997; Par-Gunnar et al., 1994; Powell et al., 1994).

Meat and meat products are a potential source of foodborne pathogens, including $S$. aureus, Salmonella spp., E. coli $\mathrm{O} 157: \mathrm{H} 7$, and B. cereus. According to the Korean Ministry for Food, Agriculture, Forestry and Fisheries (2007), the revised Processing Standard and Ingredients Standard of Livestock Product classifies meat products as "processed meat products", and thus the levels of pathogenic bacteria (i.e. S. aureus, Salmonella spp., E. coli O157:H7 etc.) do not need to be assessed, according to current regulations. A more sensitive and specific method for the detection of these pathogens in meat and meat products will help to reduce the potential health hazards they pose.

The principal objective of this study was to evaluate the reliability and applicability of using a multiplex PCR assay with built-in quality assurance measures that can be employed after culture enrichment for the routine examination of meat products for $S$. aureus, Salmonella spp., E. coli $\mathrm{O} 157: \mathrm{H} 7$, and B. cereus.

\section{Materials and Methods}

\section{Bacterial strains and DNA extraction}

The bacterial strains employed herein are listed in Table 1. The bacterial species and their origins are as follows: Staphylococcus aureus ATCC 25923, Salmonella Enteritidis KCCM 12021, Escherichia coli O157:H7, and Bacillus cereus KCCM 11341. S. aureus ATCC 25923, and E. coli $\mathrm{O} 157: \mathrm{H} 7$ were obtained from the National Veterinary Research and Quarantine Service (NVRQS, Anyang, Korea), and S. Enteritidis KCCM 12021 and B. cereus KCCM 11341 were acquired from the Korean Culture Center of Microorganisms (KCCM, Seoul, Korea). Cultures of $S$. aureus ATCC 25923, S. Typhimurium KCCM 12021, E. coli $\mathrm{O} 157: \mathrm{H} 7$, and B. cereus KCCM 11341 were initiated from freezer stocks and grown in Tryptic Soy Agar (Difco Laboratories, MD, USA). After overnight incubation at $37^{\circ} \mathrm{C}$, a single colony was selected and inoculated into $50 \mathrm{~mL}$ of Tryptic Soy Broth in a $250 \mathrm{~mL}$ Erlenmeyer flask. The cells were grown for $20-24 \mathrm{~h}$ at $37^{\circ} \mathrm{C}$ with shaking at $200 \mathrm{rpm}$.

Genomic DNA was isolated with an AccuPrep ${ }^{\circledR}$ genomic 
DNA extraction kit (Bioneer Co., Daejeon, Korea) in accordance with the manufacturer's directions, along with a modification of the cell lysis step conducted with lysozyme (Sigma Chemical Co., St. Louis, MO, USA). The density of the isolated DNA was estimated using a Spectrophotometer (Optizen 2120UV, Mecasys, Daejeon, Korea) at $\mathrm{A}_{260}$, and the DNA was eluted to a density of 20 (S. aureus ATCC 25923), 60 (S. Enteritidis KCCM 12021), 20 (B. cereus KCCM 11341), and 10 (E. coli O157:H7) ng/ $\mu \mathrm{L}$.

\section{Primer selection and PCR reactions}

The synthetic oligonucleotide primers employed herein are listed in Table 1. Four oligonucleotide primers were described previously (reference), in accordance with the determined sequence of the 23S rRNA gene (S. aureus), invA gene (Salmonella spp.), stxl/2 gene (E. coli O157: $\mathrm{H} 7$ ), and $h b l C$ gene of the HBL complex (B. cereus) (in't Veld et al., 2001; Monday et al., 2007; Rahn et al., 1992; Riffon et al. 2001).

Single PCR reactions were conducted on reference strains with each primer pair to evaluate the specificity of the primer. Each reaction mixture contained $1 \mu \mathrm{L}$ of prepared template DNA, $1 \mu \mathrm{L}$ of each reverse and forward primer $(10 \mathrm{pmol} / \mu \mathrm{L}$, final concentration: $0.1 \mu \mathrm{M}$ of each primer), $10 \mu \mathrm{L}$ of $10 \times$ buffer with $25 \mathrm{mM} \mathrm{MgCl}_{2}$ (Solis Biodyne, Tartu, Estonia), $2.5 \mathrm{mM}$ of dNTP (20 mM of dATP, dCTP, dGTP, and dTTP, Solis Biodyne), and 2.5 U of Firepol ${ }^{\circledR}$ DNA polymerase (Solis Biodyne). The final volume was adjusted to $100 \mu \mathrm{L}$ with distilled water. Multiplex PCR reactions were conducted using $4 \mu \mathrm{L}$ of the prepared template DNA mixture $(1 \mu \mathrm{L}$ of each template DNA), $8 \mu \mathrm{L}$ of $4 \times$ primer mixture $(0.1 \mu \mathrm{M}$ of each primer), and $10 \mu \mathrm{L}$ of $10 \times$ buffer with $25 \mathrm{mM} \mathrm{MgCl}$ (Solis Bio- $^{-}$ dyne, Tartu, Estonia), $2.5 \mathrm{mM}$ of dNTP (20 mM of dATP, dCTP, dGTP, and dTTP, Solis Biodyne), and 5 U of Firepol ${ }^{\circledR}$ DNA polymerase (Solis Biodyne). The final volume was adjusted to $100 \mu \mathrm{L}$ with distilled water.
PCR was conducted via the following steps: $94^{\circ} \mathrm{C}$ for 5 $\mathrm{min}, 30$ cycles of $95^{\circ} \mathrm{C}$ for $1 \mathrm{~min}, 55^{\circ} \mathrm{C}$ for $1 \mathrm{~min}$, and $72^{\circ} \mathrm{C}$ for $1 \mathrm{~min}$ with a final $7-\mathrm{min}$ extension step at $72^{\circ} \mathrm{C}$. The amplified PCR products were resolved via electrophoresis in a $1 \%$ agarose (Biopure) gel at $100 \mathrm{~V}$ for $80 \mathrm{~min}$.

\section{Specificity and sensitivity of PCR}

To evaluate the specificity of primers, PCR was conducted using purified genomic DNA with individual sets of primers from $S$. aureus, $S$. Typhimurium, E. coli $\mathrm{O} 157$ : $\mathrm{H} 7$, and $B$. cereus. The specificity of the primers was also evaluated by adding the mixture of all primer sets in multiplex PCR reactions, along with DNA obtained from individual bacteria. A mixture of DNA from $S$. aureus ATCC 25923, S. Typhimurium KCCM 12021, E. coli O157:H7, and B. cereus KCCM 11341 was also included in a separate PCR assay containing individual primers from each organism in order to evaluate the specificity.

The multiplex PCR conducted using serial dilutions of template DNA from target strains to determine the sensitivity. The sensitivity of PCR in detecting bacterial DNA was evaluated using 8 steps from $10 \mathrm{ng} / \mu \mathrm{L}$ to $1 \mathrm{fg} / \mu \mathrm{L}$ of temperature DNA.

\section{Results and Discussion}

\section{Specificity of PCR}

The specificity of PCR depends on the primers prepared against variable sequences of bacterial genes. Ideal primers should not cross-react with DNA obtained from heterologous bacteria. A number of steps were undertaken to ensure that PCR specifically detected the bacteria of choice in food. In the first step, each primer set was employed in PCR reactions with DNA from individual bacteria.

The PCR assay was capable of amplifying four DNA fragments of 1,300 bp, $284 \mathrm{bp}, 528 \mathrm{bp}$, and $622 \mathrm{bp}$ from the 23S rRNA gene of S. aureus, invA gene of Salmonella

Table 1. Primers used in PCR assay with their sequence, target gene and expected amplified DNA fragment

\begin{tabular}{|c|c|c|c|}
\hline Microorganism & Sequence & Target gene & Reference \\
\hline Bacillus cereus & $\begin{array}{l}\text { TATCAATACTCTCGCAACACCAATCG }(\mathrm{F}) \\
\text { GTTTCTCTAAATCATCTAAATATGCTCGC (R) }\end{array}$ & $\begin{array}{l}\text { hblC (L } 12 \text { component) of } \\
\text { HBL complex (977) }\end{array}$ & $\begin{array}{l}\text { in't Veld et al. } \\
\qquad(2001)\end{array}$ \\
\hline E. coli $\mathrm{O} 157: \mathrm{H} 7$ & $\begin{array}{l}\text { CTGATTGTTGAGCGAAATAATTTATATGTG (F) } \\
\text { TGATGATGACAATTCAGTATAACTGCCAC (R) }\end{array}$ & stx1/2 (528) & $\begin{array}{l}\text { Monday et al. } \\
\qquad \text { (2007) }\end{array}$ \\
\hline $\begin{array}{l}\text { Staphylococcus } \\
\text { aureus }\end{array}$ & $\begin{array}{l}\text { GGACGACATTAGACGAATCA (F) } \\
\text { CGGGCACCTATTTTCTATCT (R) }\end{array}$ & 23S rRNA (1300) & $\begin{array}{l}\text { Riffon et al. } \\
\quad(2001)\end{array}$ \\
\hline Salmonella spp. & $\begin{array}{l}\text { GTGAAATTATCGCCACGTTCGGGCAA (F) } \\
\text { TCATCGCACCGTCAAAGGAACC (R) }\end{array}$ & $\operatorname{invA}(284)$ & $\begin{array}{l}\text { Rahn et al. } \\
\quad(1992)\end{array}$ \\
\hline
\end{tabular}


spp., stx 1/2 gene of E. coli $\mathrm{O} 157: \mathrm{H} 7$, and the $h b l C$ gene of the HBL complex in B. cereus. In $S$. aureus ATCC 25923, no amplified DNA fragments were noted with primers from Salmonella, E. coli $\mathrm{O} 157: \mathrm{H} 7$, and B. cereus. Similarly, no non-specific DNA fragments were amplified when template DNA from $S$. Enteritidis KCCM 12021, E. coli O157:H7, and B. cereus KCCM 11341 was used in the PCR assay with primer sets for S. aureus, Salmonella spp., E. coli O157:H7, and B. cereus (Fig. 1).

To further confirm the specificity of the primers, a mixture of all primer sets was employed in multiplex PCR containing individual DNA from $S$. aureus ATCC 25923, $S$. Enteritidis KCCM 12021, E. coli O157:H7, and $B$. cereus $\mathrm{KCCM} 11341$ (Fig. 2). The data demonstrated that the primers did not cross-react with heterologous bacterial DNA, and rather specifically amplified analogous DNA fragments under the described PCR conditions. These results indicate that PCR can amplify DNA from the individual organisms present in food samples, even if a mixture containing primers from all organisms is employed. The primers from one organism did not interact with primers from another organism under the prescribed PCR conditions.

\section{Specificity and sensitivity of multiplex PCR reac- tion on target strains}

The primer sets successfully amplified the target genes in the multiplex PCR without any nonspecific or additional bands on the reference strains (Fig. 3). A mixture of DNA from four pathogens exhibited no inhibitory effects, and the PCR assay amplified DNA fragments of choice with specific primers only. The intensities of the bands differed depending on the number of target genes present in the strain. In a strain possessing fewer numbers of genes, the bands evidenced higher intensities, particularly in the strains yielding larger amplicons.

The sensitivity of the multiplex PCR was estimated by the minimal concentrations required to generate all of the expected bands. The highest minimal concentration of template DNA required for the reaction was approximately $10 \mathrm{pg} / \mu \mathrm{L}$.

Multiplex PCR is an essential tool for the high-throughput gene screening of pathogenic bacteria (Markoulatos et $a l ., 2002)$. In the case of Sag genes in S. aureus, however, the design of multiplex PCR primers having similar annealing temperatures, distinguishable product sizes, and high specificity without cross-reactions is extremely complicated, as there are many types of SAg genes with rela-

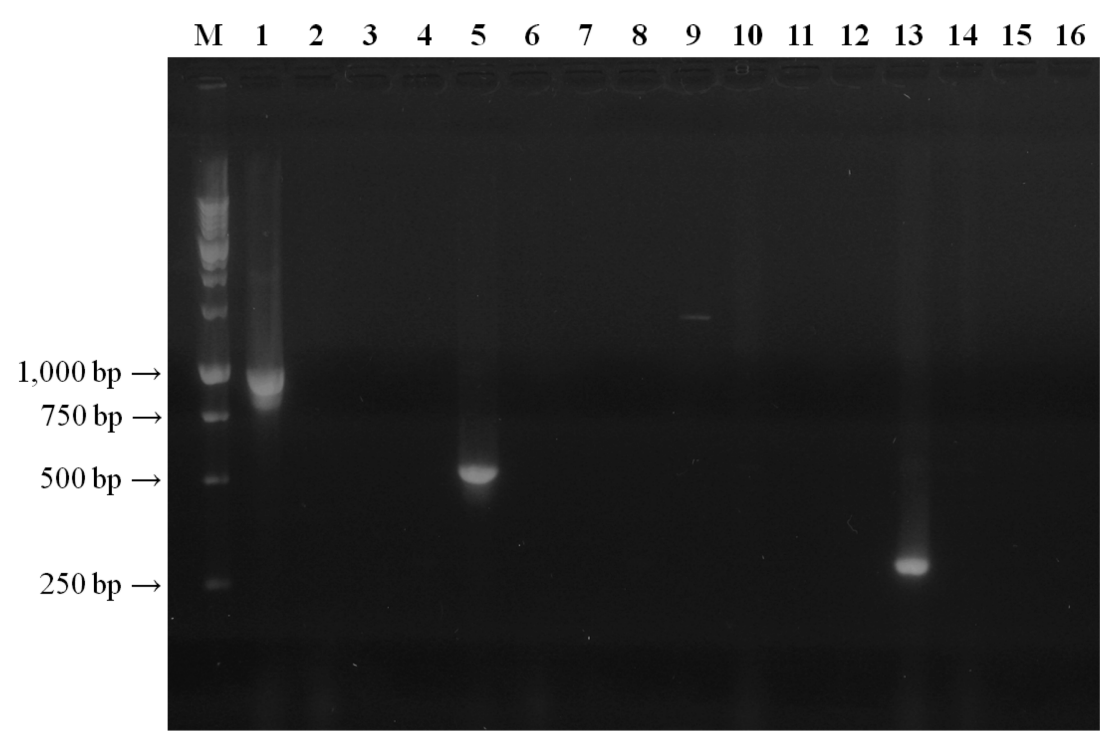

Fig. 1. Ethidium bromide-stained agarose gel showing 1,300, 284, 528, and 977 bp amplified DNA fragments from the $23 \mathrm{~S}$ rRNA gene of $S$. aureus, and invA gene of Salmonella spp., stx1/2 gene of $E$. coli $0157: H 7$, and $h b l C$ gene of $B$. cereus to demonstrate the specificity of the PCR assay. Lane 1, DNA markers; lane 2, B. cereus DNA and B. cereus specific primer; lane 3, $B$. cereus DNA and E. coli O157:H7 specific primer; lane 4, B. cereus DNA and $S$. aureus specific primer; lane $5, B$. cereus DNA and Salmonella specific primers; lane 6, E. coli O157:H7 DNA and E. coli O157:H7 specific primer; lane 7, E. coli O157:H7 DNA and B. cereus specific primer; lane 8, E. coli O157:H7 DNA and S. aureus specific primer; lane 9, E. coli O157:H7 DNA and Salmonella specific primers; lane 10, S. aureus DNA and S. aureus specific primer; lane 11, S. aureus DNA and B. cereus specific primer; lane 12, S. aureus DNA and E. coli O157:H7 specific primer; lane 13, S. aureus DNA and Salmonella specific primers; lane 14, Salmonella O157:H7 DNA and Salmonella specific primers; lane 15, Salmonella and B. cereus specific primer; lane 16, Salmonella DNA and E. coli O157:H7 specific primer; lane 17, Salmonella DNA and S. aureus specific primer. 

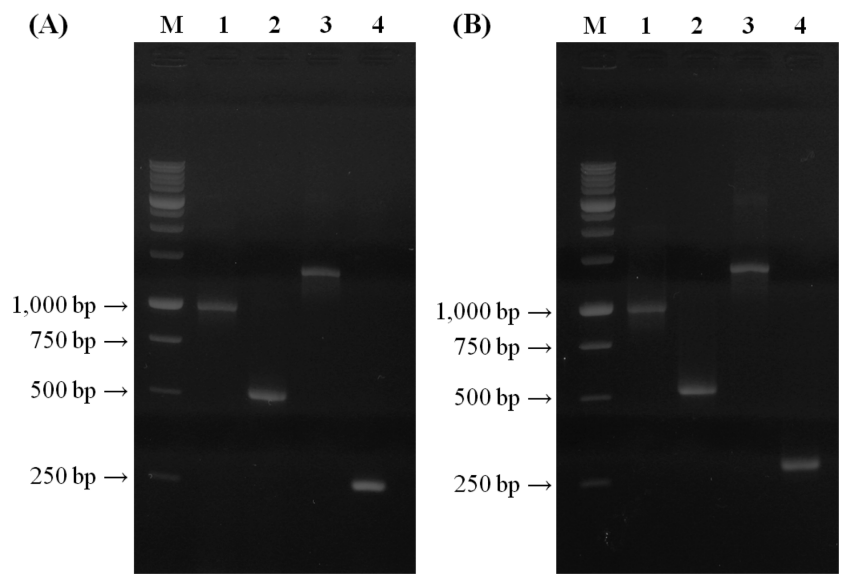

Fig. 2. Ethidium bromide stained agarose gel showing primer specific amplification of DNA fragments from $S$. aureus, Salmonella, E. coli 0157:H7, and B. cereus DNA and primers of $S$. aureus, Salmonella, $E$. coli 0157:H7, and B. cereus. (A) Lane 1, DNA markers; lane 2, PCR mixture containing $B$. cereus DNA and primers of all target genes; lane 3, PCR mixture containing $E$. coli $\mathrm{O} 157: \mathrm{H} 7 \mathrm{DNA}$ and primers of all target genes; lane 4, PCR mixture containing $S$. aureus DNA and primers of all target genes; lane 5, PCR mixture containing Salmonella DNA and primers of all target genes; (B) Lane 1, DNA markers; lane 2, PCR mixture containing all target DNA and $B$. cereus specific primer; lane 3, PCR mixture containing all target DNA and E. coli $\mathrm{O} 157: \mathrm{H} 7$ specific primer; lane 4, PCR mixture containing all target DNA and $S$. aureus specific primer; lane 5, PCR mixture containing all target DNA and Salmonella specific primer.

tively high homology (Balaban and Rasooly, 2000). Although a number of multiplex PCR systems capable of detecting target genes have been developed thus far, it is still quite difficult to evaluate these genes specifically and rapidly. In this study, we developed an easy and rapid multiplex PCR system with high specificity.

To test the sensitivity of the multiplex PCR assay, a detectable level of the DNA fragment was amplified from as small an amount of $200 \mathrm{pg}$ of purified DNA. In this study, no attempts were made to equate the CFU of bacteria with the quantity of DNA required for PCR amplification. However, it is generally believed that $10^{2} \mathrm{CFU}$ of bacteria should have at least $\times 10 \mathrm{pg}$ of DNA, which was the smallest quantity detected in the PCR when purified DNA was employed (Aslam et al., 2003). Previous studies have demonstrated that PCR is capable of detecting bacteria in food samples, but these studies employed purified or enriched cultures to isolate bacterial DNA (Lin and Tsen, 1995; Thomas et al., 1991; Velázquez et al., 2000). In this study, a direct approach was undertaken to isolate bacterial DNA in food samples without going

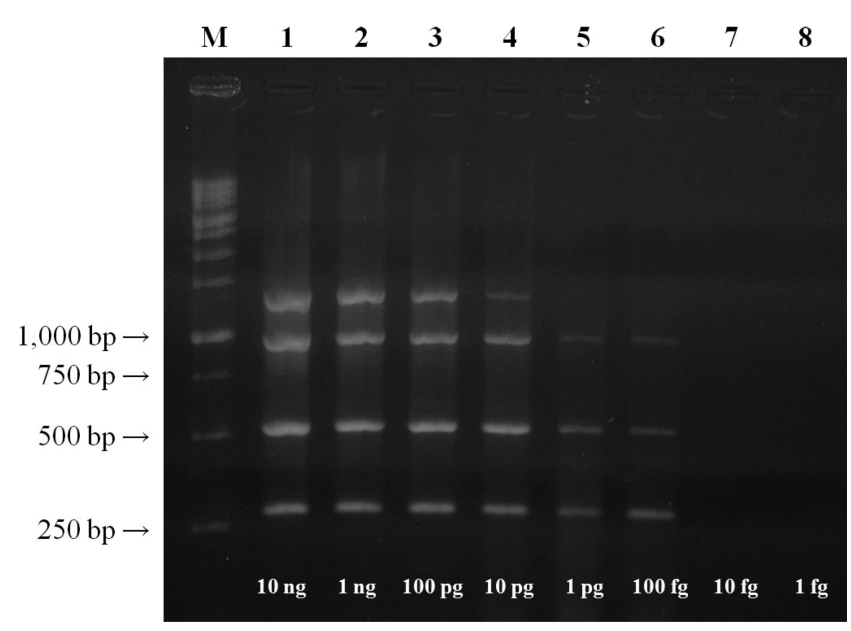

Fig. 3. Ethidium bromide-stained agarose gel showing multiplex PCR results and sensitivity of multiplex PCR. M, DNA marker and lanes 1-8, PCR mixture containing 10 ng, $1 \mathrm{ng}, 100 \mathrm{pg}, 10 \mathrm{pg}, 1 \mathrm{pg}, 100 \mathrm{fg}, 10 \mathrm{fg}$, and $1 \mathrm{fg}$ all pathogen DNA.

through any prior culture-enrichment procedures. Initially, the PCR conditions were standardized using purified bacterial DNA, and an RBM was later adopted to obtain DNA from bacterial cells in food samples. The results of previous studies have shown that sufficient quantities of DNA can be acquired by boiling bacterial cells for 10-15 min (Stewart et al., 1998). This procedure provides a rapid and efficient method of DNA isolation that can be used in PCR in a less well-equipped laboratory.

In conclusion, PCR can be employed as a sensitive and specific method for the detection of bacteria in food samples if a sufficient quantity of DNA is available for amplification. The rapid boil method is useful in isolating bacterial DNA for use in PCR assays. Our results indicate that further studies should be conducted with an eye toward improving the method of DNA isolation from bacterial cells in milk and the bacterial detection limit in PCR.

\section{Acknowledgments}

This study was supported by Technology Development Program for Agriculture and Forestry (Project: 10800202-2SB010), Ministry for Food, Agriculture, Forestry and Fisheries, and also supported by the Priority Research Centers Program through the National Research Foundation of Korea (NRF) funded by the Ministry of Education, Science and Technology (2009-0093824), Republic of Korea. 


\section{References}

1. Anonymous (2001) Report on trends and sources of zoonotic agents in the European Union and Norway. European Food Safety Authority (EFSA).

2. Aslam, M., Hogan, J., and Smith, K. L. (2003) Development of a PCR-based assay to detect shiga toxin-producing Escherichia coli, Listeria monocytogenes, and Salmonella in milk. Food Microbiol. 20, 345-350.

3. Balaban, N. and Rasooly, A. (2000) Staphylococcal enterotoxins. Int. J. Food Microbiol. 61, 1-10.

4. Bhagwat, A. A. (2003) Simultaneous detection of Escherichia coli O157:H7, Listeria monocytogenes and Salmonella strains by real-time PCR. Int. J. Food Microbiol. 84, 217224.

5. Choi, S. K., Lee, M. H., Lee, B. H., Jung, J. Y., and Choi, C. (2010) Virulence factor profiles of Escherichia coli isolated from pork and chicken meats obtained from retail markets. Korean J. Food Sci. Ani. Resour. 30, 148-153.

6. Choma, C., Guinebretière, M. H., Carlin, F., Schmitt, P., Velge, P., Granum, P. E., and Nguyen-the, C. (2000) Prevalence, characterization and growth of Bacillus cereus in commercial cooked chilled foods containing vegetables. J. Appl. Microbiol. 88, 617-625.

7. Davies, R. H. and Hinton, M. H. (2000) Salmonella in animal feed. In: Salmonella in Domestic Animals. Wray, C. and Wray, A. (eds.), CABI, Walingford, England, pp. 285-300.

8. Dinges, M. M., Orwin, P. M., and Schlievert, P. M. (2000) Enterotoxins of Staphylococcus aureus. Clin. Microbiol. Rev. 13, 16-34.

9. Gooding, C. M. and Choudary, P. V. (1997) Rapid and sensitive immunomagnetic separation polymerase chain reaction method for the detection of Escherichia coli O157:H7 in raw milk and ice-cream. J. Dairy Res. 64, 87-93.

10. Hill, W. E. (1996) The polymerase chain reaction: Application for the detection of foodborne pathogen. Crit. Rev. Food Sci. 36, 123-173.

11. in't Veld, P. H., Ritmeester, W. S., Delfgou-van Asch, E. H. M., Dufrenne, J. B., Wernars, K., Smit, E., and van Leusden, F. M. (2001) Detection of genes encoding for enterotoxins and determination of the production of enterotoxins by HBL blood plates and immunoassays of psychrotrophic strains of Bacillus cereus isolated from pasteurised milk. Int. J. Food Microbiol. 64, 63-70.

12. Jarraud, S., Cozon, G., Vandenesch, F., Bes, M., Etienne, J., and Lina, G. (1999) Involvement of enterotoxins G and I in staphylococcal toxic syndrome and staphylococcal scarlet fever. J. Clin. Microbiol. 37, 2446-2449.

13. Josephson, K. L., Gerba, C. P., and Pepper, I. L. (1993) Polymerase chain reaction detection of nonviable bacterial pathogens. Appl. Environ. Microbiol. 59, 3513-15.

14. Kim, H. W., Kim, H. J., Kim, T. H., Kim, T. I., Lee, J. Y., Kim, C. J., and Paik, H.-D. (2008) The distribution of indicator organisms and incidence of pathogenic bacteria in raw pork material used for Korean pork jerky. Korean J. Food Sci. Ani. Resour. 28, 76-81.
15. Lin, C. K. and Tsen, H. Y. (1995) Development and evaluation of two novel oligonucleotide probes based on 16S rRNA sequence for the identification of Salmonella in food. $J$. Appl. Bacteriol. 78, 507-520.

16. Lindqvist, R., Norling, B., and Lambertz, S. T. (1997) A rapid sample preparation method for PCR detection of food pathogens based on buoyant density centrifugation. Lett. Appl. Microbiol. 24, 306-310.

17. Markoulatos, P., Siafakas, N., and Moncany, M. (2002) Multiplex polymerase chain reaction: A practical approach. $J$. Clin. Lab. Anal. 16, 47-51.

18. Mead, P. S., Slutsker, L., Dietz, V., McCraig, L. F., Bresee, S., Shapiro, C., Griffin, P. M., and Tauxe, R. V. (1999) Foodrelated illness and death in the United States. Emerg. Infect. Dis. 5, 607-625.

19. MIFAFF (2007) Guideline for the National Microbiological Testing Program, In: Korean Laws and Regulations in Relation to Food Safety and Animal Health. Ministry for Food, Agriculture, Forestry and Fisheries, Gwacheon, Korea, p. 277.

20. Monday, S. R. and Bohach, G. A. (1999) Use of multiplex PCR to detect classical and newly described pyrogenic toxin genes in staphylococcal isolates. J. Clin. Microbiol. 37, 3411-3414.

21. Mondey, S. R., Beisaw, A., and Feng, P. C. H. (2007) Identification of Shiga toxigenic Escherichia coli seropathotypes A and B by multiplex PCR. Mol. Cell. Probe. 21, 308-311.

22. Munson, S. H., Tremaine, M. T., Betley, M. J., and Welch, R. A. (1998) Identification and characterisation of staphylococcal enterotoxin types G and I from Staphylococcus aureus. Infect. Immun. 66, 3337-3348.

23. Par-Gunnar, L., Hahn-Hagerdal, B., and Radstrom, P. (1994) Sample preparation methods in PCR-based detection of food pathogens. Trends Food Sci. Technol. 5, 384-389.

24. Powell, H. A., Gooding, C. M., Garrett, S. D., Lund, B. M., and McKee, R. A. (1994) Proteinase inhibition of the detection of Listeria monocytogenes in milk using the polymerase chain reaction. Lett. Appl. Microbiol. 18, 59-61.

25. Rijpens, N. P. and Herman, L. M. (2002) Molecular methods for identification and detection of bacterial food pathogens. J. AOAC Int. 85, 984-995.

26. Rossen, L., Norskov, P., Holmstrom, K., and Rasmussen, O. F. (1992) Inhibition of PCR by components of food samples, microbial diagnostic assays and DNA extraction solutions. Int. J. Food Microbiol. 17, 37-45.

27. Sarimehmetoglu, B., Aksoy, M. H., Ayaz, N. D., Ayaz, y., Kuplulu, O., and Kaplan, Y. Z. (2009) Detection of Escherichia coli $\mathrm{O} 157: \mathrm{H} 7$ in ground beef using immunomagnetic separation and multiplex PCR. Food Control 20, 357-361.

28. Scheu, P. M., Berghof, K., and Stahl, U. (1998) Detection of pathogenic and spoilage microorganisms in food with the polymerase chain reaction. Food Microbiol. 15, 13-31.

29. Simpson, M. V., Smith, J. P., Simpson, B. K., Ramaswamy, H., and Doods, K. L. (1994) Storage studies on a sous vide spaghetti and meat sauce product. Food Microbiol. 11, 5-14.

30. Stewart, D. S., Tortorello, M. L., and Gendel, S. M. (1998) 
Evaluation of DNA preparation techniques for detection of the SLT-1 gene of Escherichia coli O157:H7 in bovine faces using the polymerase chain reaction. Lett. Appl. Microbiol. 2, 93-97.

31. Tamarapu, S., McKillip, J. L., and Drake, M. (2001) Development of a multiplex polymerase chain reaction assay for detection and differentiation of Staphylococcus aureus in dairy products. J. Food Protect. 64, 664-668.

32. Thomas, E. G., King, R. K., Burckak, J., and Gannon, V. P. J. (1991) Sensitive and specific detection of Listeria monocytogenes in milk and ground beef with polymerase chain reaction. Appl. Environ. Microbiol. 57, 2576-2580.
33. Velázquez, M., Tatini, S. R., and Feirtag, J. M. (2000) Evaluation of a two step protocol for rapid detection of Salmonella in ice-cream and cheddar cheese. Food Microbiol. 17, 349-359.

34. Wang, R. F., Cao, W. W., and Cerniglia, C. E. (1997) A universal protocol for PCR detection of 13 species of foodborne pathogens in foods. J. Appl. Microbiol. 83, 727-736.

35. Wilson, I. G. (1997) Inhibition and facilitation of nucleic acid amplification. Appl. Environ. Microbiol. 63, 3741-3751.

(Received 2010.6.18/Revised 2010.7.2/Accepted 2010.7.2) 